\title{
Ut non diligat vir uxorem sicut adulteram — poglądy kaznodziejów na seksualność w średniowiecznej Polsce
}

DOI: 10.19195/2083-7763.8.2

„Jeśli mianowicie siedzi taki rozpustny młodzieniec, słuchając mądrości Arystotelesa lub Platona, duch jego uwija się na rynku albo sposobi się do biesiady, albo rozmyśla o próżnej zabawie, albo o łożu swojej nieszczęsnej kochanki” ${ }^{1}$ grzmiał z mównicy Stanisław ze Skarbimierza w 1401 roku. Przedstawiony w Mowie o złych studentach obraz życia ówczesnych żaków zawiera wiele cennych szczegółów obyczajowych, związanych zwłaszcza z kłopotami egzystencjalnymi studentów, ale niepomijających także bardziej ludycznych aspektów życia studenckiego, które szczególnie gorszyły kaznodziejów. Tworzone przez nich dzieła, potępiające wszelkie zabawy i uciechy oraz ostrzegające przed czyhającym wszędzie diabłem i jego knowaniami wśród ludzi, są nieocenionym źródłem w badaniach nad seksualnością w średniowiecznej Polsce.

Podejmując problematykę seksualności człowieka średniowiecza, należy zdawać sobie sprawę z kilku poważnych problemów. Po pierwsze, próżno w średniowiecznych źródłach szukać stosowanego obecnie terminu „seksualność, który ukształtowany został dopiero na początku XIX wieku. Znajdziemy wiele terminów oznaczających różnorodne aspekty życia płciowego, jak np. nierząd (fornicatio), nieczystość (luxuria), życie w małżeństwie (matrimonium), konkubinat (concubinatus), cudzołóstwo (adulterium) czy prostytucja (meretricatio); brakuje jednak w średniowiecznych źródłach terminu, który określałby całokształt aktywności seksualnej człowieka ${ }^{2}$. Tymczasem istnienie seksualności jest niezależne od jakiej-

1 Stanisław ze Skarbimierza, Sermo ad clerum. Mowa rektorska „O Zlych studentach”, przeł. K. Glińska, http://staropolska.pl/sredniowiecze/kazania_i_mowy/Skarbimierczyk.html (dostęp: 8.04.2016).

2 Zob. K. Skwierczyński, Mury Sodomy. Piotra Damianiego „Księga Gomory” i walka z sodomia wśród kleru, Kraków 2011, s. 17; zob. także idem, Vademecum historii średniowiecznej seksualności, „Przegląd Historyczny” 98, 2007, z. 3, s. 437-443. 
kolwiek kultury, a jej przejawy są widoczne w każdej społeczności. Nie każda kultura przywiązuje jednak takie samo znaczenie do roli zachowań erotycznych; o ile bowiem sam popęd płciowy jest zjawiskiem biologicznym, seksualność jest w każdej cywilizacji determinowana kulturowo, co oznacza, że poszczególne przejawy realizacji popędu seksualnego mogą być postrzegane w różny sposób.

Przede wszystkim należy liczyć się z faktem, że podjęcie tej problematyki niezależnie od obszaru badawczego - wiąże się z utrudnieniem wynikającym $\mathrm{z}$ rodzaju zachowanych źródeł. Badacze skazani są bowiem głównie na informacje i postulaty przekazane w pismach teologów, kaznodziejów, jurystów czy też artystów. Znacznie bardziej skomplikowanym wyzwaniem jest zrekonstruowanie poglądów i opinii charakterystycznych dla przeciętnego przedstawiciela danej grupy społecznej. Wiele spośród występujących we współczesnych społeczeństwach zachowań seksualnych (o ile nie wszystkie) mogło występować także w średniowieczu, jednak ze względu na ograniczenia źródłowe nie wszystkie są dla nas kulturowo widoczne. Podobnie możliwe jest istnienie $\mathrm{w}$ średniowieczu różnorodnych poglądów na pewne kwestie, jednak w związku z dominacją dyskursu kościelnego zmuszeni jesteśmy badać seksualność przez jego pryzmat ${ }^{3}$. Można więc próbować dowiedzieć się, które zachowania umotywowane popędem płciowym były dozwolone, a które potępiane, co było narzucane, a co wymykało się wszelkiej kontroli - inaczej mówiąc, co społeczeństwo średniowiecznej Polski uznawało za słuszne i potrzebne oraz czego zakazywało ze względu na wyznawane przez siebie wartości. Takie badania są możliwe dzięki źródłom o charakterze moralizatorskim, a zatem przede wszystkim tekstom kaznodziejskim.

Kazania, układane najczęściej w zbiory zwane sermones, były podstawową formą przekazywania wiernym głównych prawd wiary i zasad etyki chrześcijańskiej. Do rozwoju nowego gatunku prozy łacińskiej w znacznym stopniu przyczyniły się postanowienia Soboru Laterańskiego IV. Rosnące od XIII wieku w Polsce zapotrzebowanie na zbiory Sermones de sanctis lub Sermones de tempore ściśle związane było z rozwojem struktur parafialnych i realizowaniem programu zakładającego głoszenie kazań w języku narodowym, opartych na łacińskich wersjach pisanych. Polskie kazania w znacznej mierze były kształtowane pod wpływem wzorów zachodnio- i południowoeuropejskich, ale też zgodnie z regułami wyłożonymi w podręcznikach sztuki kaznodziejskiej ${ }^{4}$. Wiele popularnych sermones, kierowanych do mas wiernych o nierównym poziomie wykształcenia, powstawało pod piórem wykładowców Akademii Krakowskiej, łączących pracę naukową z działalnością kaznodziejską. Nie bagatelizowano zatem roli sermones przeznaczonych dla mas - ich zbiory były przekładane na język polski przez znakomitych uczonych, cieszących się nierzadko ogromnym szacunkiem wiernych ${ }^{5}$.

\footnotetext{
3 Ibidem, s. 23.

4 Zob. T. Michałowska, Literatura polskiego średniowiecza. Leksykon, Warszawa 2011, s. 248.

5 Ibidem, s. 250.
} 
Kazania te różniły się jednak znacząco od mów adresowanych do odbiorców wykształconych $-\mathrm{z}$ uwagi na zróżnicowany status społeczny i poziom intelektualny wiernych musiały operować prostymi objaśnieniami i posługiwać się exempla$m i$, tak aby przekazywane w nich treści były czytelne dla każdego odbiorcy i skutecznie spełniały funkcję umoralniająco-edukacyjną. Jest to szczególnie istotne w kontekście prowadzonych badań, ponieważ wzmacnia wiarygodność opisywanych w tekstach kaznodziejskich zachowań: potępiane z kazalnicy grzeszne postawy musiały być zrozumiałe dla słuchaczy (doskonale pojmujących treść kazania wygłaszanego w ich języku), a może nawet znane im z obserwacji. Jak słusznie zauważył Krzysztof Bracha, badający tzw. kolekcję Piotra z Miłosławia, owe sermones ad populum „odchodzily od wysublimowanych i hermetycznych treści teologicznych na rzecz wykładu dostępnego percepcji i wyobraźni wiernych"6. Szczególna wartość tego rodzaju kazań dla prowadzonych badań wynika z zawartych w nich opisów grzesznych, gorszących kaznodziejów postaw, które stanowią - wbrew intencji duszpasterskiej - bezcenny materiał źródłowy, pozwalający poznać realia ówczesnego życia poszczególnych środowisk społecznych. Co więcej, przechowują one pamięć (znowu niezamierzenie) o polskich piosenkach swawolnych oraz o pieśniach towarzyszących tańcom ${ }^{7}$.

Kazania szczególnie nas interesujące - ze względu na ich użyteczność w badaniach nad seksualnością - pochodzą z tzw. kolekcji Piotra z Miłosławia, wnikliwie zbadanej przez K. Brachę ${ }^{8}$. Wśród autorów tekstów znajdujących się w kolekcji, błędnie przypisywanej Piotrowi z Miłosławia (który był jedynie jej kompilatorem), znaleźć można kilku najznakomitszych kaznodziejów $\mathrm{XV}$ wieku, związanych głównie ze środowiskiem krakowskim: Pawła z Zatora, Jana ze Słupczy, Łukasza z Wielkiego Koźmina, Jana Szczeknę (kaznodzieję czeskiego, spowiednika królowej Jadwigi), Mateusza z Krakowa (profesora teologii na Uniwersytecie w Heidelbergu, późniejszego biskupa wormackiego), a także Jana Sylwana z Pragi. To zestawienie wskazuje niezaprzeczalnie na ogromny wpływ środowiska krakowskiego na teksty omawianych kazań oraz na wyraźny ślad autorów związanych ze środowiskiem praskim. Kompilacyjna praca Piotra z Miłosławia zyskała ogromną popularność i stała się najprawdopodobniej, jak zaznaczył Bracha, kolekcją wzorcową, za czym przemawia kilka argumentów. W zawartych w kolekcji tekstach pojawiają się powtarzalne w polskim piśmiennictwie kaznodziejskim wątki obiegowe, pieśni i przysłowia; na marginesach kazań zamieszczano obszerne komentarze współczesnych glosatorów, również świadczące o popularności kolekcji. Najlepszym potwierdzeniem atrakcyjności zbio-

${ }^{6}$ K. Bracha, Nauczanie kaznodziejskie w Polsce późnego średniowiecza, Kielce 2007, s. 35.

7 T. Michałowska, op. cit., s. 251.

8 Oprócz cytowanej pracy Brachy na uwagę zasługuje także jego artykuł: idem, Wokół tysogórskich kolekcji kazań $z$ XV w. przypisywanych Piotrowi z Miłosławia. W kręgu małżeństwa i rodziny, [w:] Klasztor na Świętym Krzyżu w polskiej kulturze narodowej, red. D. Olszewski, R. Gryz, Kielce 2000, s. 85-103. 
ru jest jednak liczba kopii rękopiśmiennych: do naszych czasów przetrwało pięć, a w XV wieku mogło ich być, w przekonaniu Brachy, przynajmniej dwa razy więcej. Skoro zatem interesujące nas źródła pochodzą z ",najpopularniejszej kolekcji w polskim kaznodziejstwie późnego średniowiecza", o zasięgu ogólnopolskim, można domniemywać, że wszelkie zawarte w niej egzemplifikacje piętnowanych przez kaznodziejów postaw są miarodajne dla duszpasterstwa kościoła polskiego i przeznaczone dla całego społeczeństwa. Nie zachodzi więc obawa, że mamy do czynienia $\mathrm{z}$ wyizolowanymi, pojedynczymi przykładami charakteryzującymi jedynie środowisko, z którego źródło się wywodzi, i mający niewiele wspólnego $\mathrm{z}$ innymi terenami średniowiecznej Polski.

Tematy kazań z kolekcji Piotra z Miłosławia dotyczą zarówno Eucharystii i ważnych dla wiernych problemów eschatologicznych (zwłaszcza śmierci, Sądu Ostatecznego, miejsca przebywania duszy po śmierci itp.), jak i istoty największych świąt kościelnych i związanych z nimi obrzędów. Pojawiają się także kazania odnoszące się do różnorodnych zagadnień życia społecznego, m.in. problemów rodzinnych i małżeńskich, oraz potępiające grupy marginesu społecznego, czyli kuglarzy, czarownice, ludzi „ulic i placów”, a zatem środowiska kojarzonego $\mathrm{z}$ rozpustną zabawą, co dało z kolei przyczynek do napiętnowania grzechów kojarzonych $\mathrm{z}$ ich działalnością, takich jak taniec, swawolne pieśni miłosne itp. ${ }^{10}$ Ulubionym tematem omawianej kolekcji jest jednak zdecydowanie etyka małżeńska i rodzinna będąca przedmiotem szczególnego zainteresowania Kościoła, zwłaszcza po Soborze Laterańskim IV, kiedy małżeństwo zostało ostatecznie uznane za sakrament.

Postulaty duszpasterzy dotyczące relacji małżeńskich zostały oddane w najpełniejszy sposób w cyklu dwóch kazań przeznaczonych na czas tuż po oktawie Epifanii. Wygłaszane wówczas kazania dotykały zazwyczaj właśnie problematyki małżeńskiej, co wiąże się ściśle z kalendarzem liturgicznym: kończył się okres zakazów zawierania małżeństw, a zaczynał czas wesel i ślubów ${ }^{11}$. Interesujące nas kazania, Dominica prima post octavas Epiphaniarum (oznaczone w kolekcji numerem 24) oraz Nupcie facte sunt in Cana Galilee (numer 25), przypisywane są Łukaszowi z Wielkiego Koźmina (1370-1412) i pochodzą najprawdopodobniej z jego postylli z 1412 roku - Sermones triplices de tempore ${ }^{12}$.

Już w pierwszych słowach kazania nr 25 kaznodzieja wyjaśnia, że wiedza dotycząca pożycia małżeńskiego jest szczególnie istotna, gdyż „owe trudne więzy mają w sobie wiele zawiłości” ${ }^{13}$. Nie oznacza to jednak, że małżeństwo w ogóle nie jest przez Boga aprobowane - gdyby tak było, „Bóg nie stworzyłby Ewy jako

9 Ibidem, s. 88-89.

10 Zob. T. Michałowska, op. cit., s. 251; K. Bracha, Wokół łysogórskich kolekcji kazań..., s. 89.

11 Zob. K. Bracha, Nauczanie kaznodziejskie..., s. 238.

12 Zob. K. Bracha, Wokót tysogórskich kolekcji kazań..., s. 90.

13 [...] status habet in se multos vncos wanszlow trudnych, Sermo 25, Cod. BN III 3021, f. 58rb, cytaty kazań w wersji oryginalnej oraz ich tłumaczenia za: K. Bracha, Nauczanie kaznodziejskie... (s. 239). 
partnerki dla Adama; uznał jednak, że mężczyzna potrzebuje kobiety, aby go wspierała" ${ }^{14}$. Kaznodzieja był jednak doskonale świadomy faktu, że praktyka życia codziennego znacznie odbiegała od postulowanego przez naukę chrześcijańską i dogmatykę kościelną modelu współżycia między małżonkami. „Skoro ci, którzy trwają w małżeństwie, łatwiej osiągają zbawienie, gdyż jeden drugiego pobożnie wspiera”, to dlaczego, zastanawiał się kaznodzieja, „tyle w stanie małżeńskim nieprawości i bezeceństw? Małżeństwo jest jednym z siedmiu sakramentów Kościoła, dlaczego zatem go nie poważacie, lecz z powodu gorszących czynów sprowadzacie nieład?”15. Jak się okazuje, „powodów jest wiele - z jednej strony wyuzdane słowa i nieobyczajne rozmowy" (verba inordinata accione et detestabili conversacione), z drugiej zaś niegodne i bezwstydne pożycie cielesne. „Często bowiem małżonkowie trwają w związku jak nierozumne zwierzęta, jak koń z mułem lub jak cudzołożnik z cudzołożnicą ${ }^{16 ”}$. Kaznodzieja wyraża tym samym topiczny w etyce małżeńskiej pogląd - wypowiedziany wprost w innym kazaniu z tej samej kolekcji - że „nic nie jest bardziej odrażające niż kochać żonę jak cudzołożnicę ${ }^{17 ”}$. Kochanie żony jak cudzołożnicy oznaczałoby łamanie wyznaczonych zasad określających ramy, w obrębie których dopuszczalne jest pożycie cielesne małżonków — zarówno jeśli chodzi o czas, jak i sposoby współżycia. Jeżeli owe zasady nie są przestrzegane, wówczas „żona, zamiast być podporą w małżeństwie, często bywa podporą w potępieniu”. Dzieje się tak zwłaszcza wtedy, gdy „mężowie wymagają od swoich niewiast niezwyczajnych aktów cielesnych, a więc niezgodnych z naturą, lecz na sposób zwierzęcy, a nawet sodomicki lub w niestosownym, zabronionym czasie, na przykład w dni świąteczne, w czasie dni postnych, a ponadto $\mathrm{w}$ miejscach świętych lub w okresie menstruacji, lub gdy kobieta jest brzemienna" ${ }^{18}$. Związek małżeński nie powinien zatem opierać się na namiętności, lecz raczej na wzajemnym wsparciu i pomocy na drodze do zbawienia. Stosunki cielesne pojmowane były jako wzajemna powinność chroniąca przed niewiernością, a także jako konieczność prowadząca do zrealizowania najważniejszego celu małżeństwa — spłodzenia

14 Sermo 24, Cod. BN III 3021, f. 56vb (s. 240).

15 Ex quo enim status vester est sacramentum unum de septem sacramentis ecclesie, quamobrem illud non honoratis, sed illud confunditis actibus detestabilibus, Sermo 25, f. 59ra; Sermo 20, Cod. BN III 3021, f. 46vb (s. 239-240).

16 [...] in vestro statu permanetis sicut equus et mulus, in quibus non est intellectus [...] Manentes non quemadmodum maritus cum uxore, sed tanquam adulter cum adultera, Sermo 25, f. 59ra (s. 240).

17 Ut non diligat vir uxorem sicut adulteram. Quia dicit Jeronimius. Adulter est, qui in suam uxorem est amator ardencior. Nihil enim fetidius quam uxorem quasi adulteram amare, Sermo 77, f. 231vb-232ra (s. 240).

18 [...] dedit quippe Deus viris uxorem sociam et adiutorem salutis non dampnacionis [...] Tunc etenim uxor est tibi adiutorium dampnacionis, quando exigis ab ea actus tuos carnales modo non naturali, sed brutali sodomitico [...] Quandoque virum prohibet, ne thori postulet actus et festa, sacerque locus, ieiunia, menstrua, partus. Quandoque modis peccat uxore maritus abutens tempore sive loco condicione modo, ut faciat, vitet, fecundet, ut debitum solvat, peccatum mortale, quod sequitur est veniale, Sermo 25, f. 59ra-b i Sermo 33, Cod. BN III 3021, f. 80rb-80va (s. 241). 
potomstwa. Otoczenie aktu seksualnego licznymi zakazami wiązało się m.in. (poza aspektami związanymi z moralnością chrześcijańską) właśnie z potrzebą realizacji głównej powinności małżonków. Jak tłumaczy Bracha, „ciało kobiety, przyszłej matki, niestałe i narażone na cykliczną nieczystość oraz uległość wobec grzesznych żądzy, podlegało szczególnej ochronie w trosce o prawidłowy przebieg prokreacji ${ }^{19 "}$. Kaznodzieje przestrzegali przed niebezpieczeństwem chorobowych następstw grzesznej prokreacji, posługując się interpretacją demonologiczną: wyjaśniano, że rozpusta odbija się nieuchronnie na poczęciu, a wszystko za sprawą Asmodeusza, symbolu rozpusty i cielesnego wyuzdania, „którego Bóg dziś jeszcze zsyła na ludzi jako karę za podobne czyny, rozpustę i wyuzdanie"20. W jaki sposób można uniknąć zagrożeń i błędów związanych ze stanem małżeńskim? Jak tłumaczył kaznodzieja, należy uprzednio wybrać odpowiednią żonę, rozważając urodzenie panny (genus), jej obyczaje (mores) i reputację (fama). Właściwy wybór ma bowiem służyć utrzymaniu $\mathrm{w}$ rodzinie harmonii, która może nastać jedynie wówczas, gdy mąż dominuje nad żoną. W przeciwnym razie, kiedy ciało (czyli żona) dominuje nad duszą (czyli mężem), harmonia jest zaburzona, co z kolei jest przyczyną wszelkich nieporozumień i problemów ${ }^{21}$. Wówczas między takimi kłótliwymi małżonkami „nie słyszy się niczego więcej oprócz zrzędzenia i chrapania”. Aby tego uniknąć, należy zawczasu zdobyć wszelkie informacje o obyczajach i postawie moralnej potencjalnej kandydatki na żonę, zdecydowanie mniejszą uwagę należy zaś przywiązywać do jej wyglądu — jednak, jak z ubolewaniem wypominał kaznodzieja, tak dzieje się najczęściej. Kaznodzieja tłumaczył zatem wiernym, że wygląd kobiety jest zgubny, gdyż „taka panna budzi pożądanie wielu i trudno ją upilnować”, ponadto „zewnętrzne powaby niewiasty trwają tylko do czasu, a mores nieprzerwanie". Aby łatwiej trafić do mentalności słuchaczy i odwołać się do tzw. ludowej mądrości, kaznodzieja przytoczył zwrotkę popularnej pieśni „Nie wybiraj, junochu, oczyma..."22

Na podstawie przytoczonych zaleceń nie sposób nie odnieść wrażenia, że wygląd kobiety był dla poszukujących żony mężczyzn bardzo istotną kwestią. Gdyby było inaczej, zbędne byłoby tak wielkie zaangażowanie $\mathrm{w}$ propagowanie zupełnie przeciwnej postawy. Często kierowano się właśnie aparycją panny, nad czym kaznodzieje ubolewali i na co starali się znaleźć sposób. Nieprawdą jest zatem, że wyborem żony kierował jedynie pragmatyzm niepozostawiający miejsca na romantyczne motywacje. Rozumieli to zachodni moralizatorzy niewykluczający roli miłości i wrażliwości na kobiecą urodę. Aelred z Rievaulx wyjaśniał rolę miłości w małżeństwie, powołując się na prawa natury: „W akcie cielesnym powstaje generationis materia tylko pod warunkiem, że między obojgiem panuje miłość (amor)

19 K. Bracha, Nauczanie kaznodziejskie..., s. 261.

20 Sermo 25, f. 59rb (s. 242).

21 Sermo 55, Cod. BN III 3021, f. 162vb (s. 248).

22 Sermo 25, f. 59vb-60ra (s. 250). 
oraz wzajemna wola i przyjemność (delectatio)". Dwunastowieczny kaznodzieja podkreślał także, że - aby ustrzec się bezpłodności - konieczne jest odczuwanie przyjemności przy prokreacji. Jego poglądy podzielał Hugon ze św. Wiktora, który kładł szczególny nacisk na wzajemną miłość małżonków jako podstawowego dobra związku. Były to jednak poglądy oryginalne w epoce i niestety nie natrafiliśmy na ślady podobnych opinii w polskim kaznodziejstwie ${ }^{23}$.

Taniec oraz towarzyszące mu piosenki miłosne (cantica amatoria / luxuriosa) potępiano z nie mniejszą gorliwością niż grzeszną prokreację. Szczególnie ostro zwalczano pieśniarki, które porównywano do sów i zwodniczych syren ${ }^{24}$. W przekonaniu kaznodziejów najwięcej rozpustnych zabaw odbywało się w czasie ostatnich dni karnawału, kiedy to panowanie nad ludźmi przejmował bóg Carnisprivium. Jego kapłanami i urzędnikami byli jokulatorzy, muzycy, śpiewacy i rozmaici przebierańcy, którzy sprawiali, że na ulicach i w karczmach tłumy ludzi oddawały się nieprzystojnym rozrywkom: muzykanci przygrywali na piszczałkach i cytrach szaleńczym tańcom i korowodom, wszędzie słychać było rozpustne piosenki i bezwstydne słowa (verba turpia) ${ }^{25}$. Możliwy kształt wykonywanych wówczas piosenek miłosnych może przybliżyć nam tzw. Cantilena inhonesta (nazywana też Skarga na pannę), której jedyny zachowany zapis, pochodzący z roku 1416 lub 1417, znajduje się w łacińsko-czesko-niemieckim kodeksie należącym do Mikołaja z Koźla. Utwór miał być wykonywany przez histriona, a więc wykonawcę potępianego przez władze kościelne i świeckie; w przekonaniu Teresy Michałowskiej niemało tego rodzaju pieśni musiało wówczas krążyć w obiegu ustnym, ale jedynie ta została ocalona, przez zupełny przypadek. Tekst utworu został wydany m.in. w Chrestomatii staropolskiej ${ }^{26}$; oto jego początek:

Chcy ja na pannu żałować / Nie chciałat' mi trochy dać / Memu koni owsa. / Mniszli ty, panno, bych był mat? / U mniet' wisi jako *skal / Nożyk przy biedrzycy. / Rożż̇y, panno, świecyczku, / Przysuczywa dratwiczku, / Jako pirwe było.

Utwór interpretowanyjest jako miłosna zachęta młodzieńca kierowana do opornej dziewczyny. Otwierająca pieśń skarga na pannę pełna jest erotycznych aluzji i dwuznaczności wyrażonych przez przejrzystą dla odbiorcy metaforykę (np. koń, nóż przypasany u pasa). Z kolejnych wersów wynika, że mimo niepowodzeń młodzieniec nie ustaje w próbach zdobycia dziewczyny:

Na pisane pierzynie / Damy sobie do wole Piwa i miedu / Rozżży, panno, kahaniec / Ohledawa hned wianiec / Jeszczeli je cał / A ktorak może cał byci / Dałaś z tym ji starhaci / Kto pirwe przybieht /Mniszli, panno, bych byt ślep? / Uderzym ja kijem w kierz / Wyżenu zajece.

23 Ibidem, s. 252.

24 Ibidem, s. 144.

25 Ibidem.

${ }^{26}$ Chrestomatia staropolska. Teksty do roku 1543, red. W. Wydra, W.R. Rzepka, Wrocław 2004, s. 293. 
Wyrażenia związane z czynnościami seksualnymi zostały tu zastąpione podobnie brzmiącymi słowami, np. „kierz” (krzak) zamiast „kiep”27.

Miejscami wykonywania owych cantica luxuriosa były dwory królewskie, możnowładcze i biskupie, domy bogatych mieszczan krakowskich, a także gospody lub po prostu otwarte miejsca w miastach (place, ulice), a w wypadku wsi dogodne miejsca przy drogach. Obyczaj biesiadny na dworze królewskim potępił w XV wieku kaznodzieja Mikołaj z Błonia, pisząc, że wykonywaniu piosenek przez jokulatorów, rozpustnych śpiewaków (cantores luxurioses), towarzyszą nierządne gesty, treść utworów jest zaś swawolna (cantilenae lascivae) i nieprzyzwoita (turpes cantilenae). Nasilająca się w XIV i XV wieku krytyka, jak również zakazy wykonywania i słuchania cantilenae, przyczyniły się - wbrew intencji duszpasterskiej - do utrwalenia pamięci o nich.

Nie mniej gorszącą „manifestacją lubieżnego pożądania i kuszenia” był w oczach duszpasterzy taniec ${ }^{28}$. Jego krytyka dotyczyła nie tylko potańcówek, jakie miały miejsce w karczmach, lecz także wszelkiego rodzaju tańca związanego z tradycyjną obrzędowością, a nawet takiego, jaki był odbywany w czasie mszy prymicyjnych. Nie zapominano jednak, że "nie tyle sam taniec jest potępiony, skoro Zbawiciel nakazywał chwalić siebie wśród bębenków", ile towarzyszące mu okoliczności sprzyjające zazwyczaj chuciom cielesnym ${ }^{29}$. Tańcząca para jest bowiem „niczym dwa iskrzące kamienie, które pocierane ze sobą wywołują iskrę pożądania" ${ }^{30}$. Służą temu, jak wyjaśniał kaznodzieja, nie tylko taneczne gesty, mimika twarzy, rzucane sobie spojrzenia i „słowa panien o mocy ognia, pieśni swawolne o miłości do oblubieńca, którymi pobudzają się wzajemnie”, lecz także „dotyk i wzajemne objęcia oraz wyrazisty widok twarzy tańczących, gdyż nikt nie tańczy z pochyloną głową," co jest szczególnie niebezpieczne, gdyż wówczas „z twarzy kobiet bucha palący ogień" ${ }^{31}$. Ten pogląd zdecydowanie podzielał austriacki kaznodzieja Konrad Waldhauser (1326-1369), porównujący kobiety do narzędzi diabła, które „rozognionym licem, wzrokiem, spojrzeniem i rozmową rozpalają męskie serca ${ }^{32}$ ". Jak się jednak okazuje, owe płomienne spojrzenia nie są jedynym narzędziem zwodniczych kobiet; Mikołaj z Koźla (przed 1390-po 1431) tłumaczył, że tym samym celom służą „powabne stroje, żółte woalki i złote wianki na głowach, którymi panny wabią i mamią w tańcu". Nie bez powodu kaznodzieja nie wspomniał o czynnym udziale mężczyzn w owej zabawie, powszechnie

27 M. Włodarski, Wstęp, [w:] Polska poezja świecka XV wieku, oprac. M. Włodarski, Wrocław 1997, s. LXXVII-LXXVIII.

28 Zarzuty dotyczące tańca zawierają kazania nr 35 i 48 (Cod. BN III 3021).

29 Tamen Deus precipit se laudari in choro, in tympano. [...] Igitur peccatum non est verum, si non fuerunt circumstancie peccati, Sermo 35, f. 88vb (s. 344).

30 [...] collisione duorum lapidum frigidorum ignis excuttitur, Sermo 35, f. 89ra (s. 345).

31 Ibi eciam est expressa visio facierum, quia nullus depraesso capite corizat. [...] Sed ex quo facies mulierum est ardens ignis, facies autem veri est stuppa, que facile igne assumitur (s. 346).

${ }^{32}$ Unde ignie luxurie in cordibus virorum accendunt, ibidem. 
uznawano bowiem taniec za atrybut przede wszystkim niewieści, grzech kobiet i dziewcząt; mężczyzn uważano raczej za ofiary zalotów. W przekonaniu kaznodziei „obłudne rozmowy, wyzywające spojrzenia, kolor szat, a także dotyk rąk lub wyraz twarzy” służyły do „ranienia męskich serc”33.

Środowiskiem szczególnie podatnym na zepsucie i rozwiązłość było w oczach kaznodziejów grono żakowskie. Nad przywarami młodych studentów ubolewał Stanisław ze Skarbimierza w przywołanej już Mowie o złych studentach, wygłoszonej na otwarcie semestru letniego w 1401 roku. Była to prawdopodobnie pierwsza na Akademii Krakowskiej mowa rektorska rozpoczynająca semestr, stanowiąca wprowadzenie do odczytywanych następnie statutów. Mowa o złych studentach miała pouczyć nowo wpisanych żaków, jak mają się zachowywać podczas studiów, a starszym członkom wszechnicy przypomnieć o ich obowiązkach ${ }^{34}$.

Są na przykład włóczędzy, zwani też studentami, którzy, chociaż odwiedzają wykłady magistrów, nie są jednak znani matce-Uniwersytetowi, ponieważ zatajają nazwisko przed wpisem, przed metryką Uniwersytetu; [...] Nie przebywają też z magistrami w bursach, lecz raczej z kochankami w hospicjach (cum amasiis in hospiciis commorantur) $)^{35}$

— utyskiwał kaznodzieja.

Są i inni, którzy nawet jeśli są wpisani, jednak albo słuchają wykładów magistrów przysypiając, albo rzadko, a nawet wcale [ich] nie odwiedzają, za to niemal codziennie przyłączają się do widowisk lub zabaw, swawoli lub sprośności. [...] Jeśli mianowicie siedzi taki rozpustny młodzieniec, słuchając mądrości Arystotelesa lub Platona, a zwłaszcza prawdy Salomonowej Jezusa Chrystusa w lektorium, duch jego uwija się na rynku albo sposobi się do biesiady, albo rozmyśla o próżnej zabawie, albo o łożu swojej nieszczęsnej kochanki. Nic w tym jednak dziwnego, ponieważ mówi Prawda: „gdzie jest twój skarb, tam będzie i serce twoje”36.

\section{Na tym jednak grzechy studentów się nie kończą, albowiem}

są inni, których widziano przystających z karczmarzami i kobietami, [którzy] nieznani [są] magistrom i doktorom, nie przebywają bowiem $\mathrm{z}$ innymi magistrami, ale w towarzystwie błaznów lub ciągnących ku zmysłowym dobrom i słodkiej truciźnie zbytku zwodniczych kobiet ${ }^{37}$.

\section{Ibidem.}

34 Sermo ad clerum de malis studentibus, wyd. Z. Kozłowska-Budkowa, „Biuletyn Biblioteki Jagiellońskiej” 15, 1963, s. 11; tłumaczenie Mowy za: K. Glińska, http://staropolska.pl/sredniowiecze/kazania_i_mowy/Skarbimierczyk.html (dostęp: 8.04.2016).

35 [2] Ut sunt girovagi vel vocati studentes, qui, quamquam lectiones magistrorum visitant, son tamen Universitatem matrem esse agnoscunt, quia se ab inscriptione, ab Universitatis matricula abscondunt [...] Nec cum magistris in bursis, sed pocius cum amasiis in hospiciis commorantur, Sermo ad clerum..., s. 16.

36 [3] Et isti etiam erant appropinquantes ad studium ore et non corde, corpore sed non mente. Sedet siquidem lascivus iuvenis, audiens sapienciam Aristotilis vel Platonis et presertim veri Salomonis Jesu Christi in lectorio et animus suus volutatur in foro, aut disponit de convivio, vel meditatur de inutili ludo, aut sue infelicis amatricis lecto, ibidem.

37 [7] Sunt alii, quorum conversacio nota est pincernis et mulieribus, ignota magistris et doctoribus, nam non morantur cum cetu magistrorum, sed cum societate scurrarum, aut trahencium ad carnalia et veneno luxurie ipsos infatuancium mulierum, ibidem, s. 17. 
Środowisko studentów wydaje się zatem wyjątkowo podatne na czyhające wszędzie pokusy świata doczesnego.

Nie sposób zaprzeczyć, że zawarte w źródłach kaznodziejskich przestrogi oraz postulaty umożliwiają przede wszystkim poznanie poglądów Kościoła na liczne kwestie związane z seksualnością człowieka średniowiecznego. W związku z tym wysnuwanie na takiej podstawie wniosków na temat poglądów charakterystycznych dla tzw. szarego człowieka może wydawać się ryzykowne. Należy jednak jeszcze raz podkreślić, że wszelkie przykłady grzesznych zachowań, przywoływane przez kaznodziejów, musiały być wiarygodne dla słuchaczy, być może nawet znane im z obserwacji - dotyczy to zwłaszcza kazań ad populum, kierowanych do wiernych o zróżnicowanym poziomie intelektualnym, których autorzy troszczyli się przede wszystkim o przystępność przekazu i operowali nieskomplikowanymi objaśnieniami. Przywoływane w źródłach kaznodziejskich grzeszne zachowania, których motywacją był popęd seksualny, wzbudzają zatem zaufanie i można $z$ bardzo dużym prawdopodobieństwem uznać je za charakterystyczne dla obyczajowości mieszkańców średniowiecznej Polski.

\section{Bibliografia}

Źródta

Chrestomatia staropolska. Teksty do roku 1543, red. W. Wydra, W.R. Rzepka, Wrocław 2004.

Sermo 24, Cod. BN III 3021 (fragmenty), [w:] K. Bracha, Nauczanie kaznodziejskie w Polsce późnego średniowiecza, Kielce 2007.

Sermo 25, Cod. BN III 3021 (fragmenty), [w:] K. Bracha, Nauczanie kaznodziejskie w Polsce późnego średniowiecza, Kielce 2007.

Sermo 55, Cod. BN III 3021 (fragmenty), [w:] K. Bracha, Nauczanie kaznodziejskie w Polsce późnego średniowiecza, Kielce 2007.

Sermo ad clerum de malis studentibus, wyd. Z. Kozłowska-Budkowa, „Biuletyn Biblioteki Jagiellońskiej” 15, 1963, http://staropolska.pl/sredniowiecze/kazania_i_mowy/Skarbimierczyk.html.

\section{Literatura}

Belcarzowa E., Glosy polskie w łacińskich kazaniach średniowiecznych, t. 1-5, Wrocław-Kraków 1981-2001.

Bracha K., Nauczanie kaznodziejskie w Polsce późnego średniowiecza, Kielce 2007.

Bracha K., Wokół tysogórskich kolekcji kazań z XV w. przypisywanych Piotrowi z Miłosławia. W kręgu małżeństwa i rodziny, [w:] Klasztor na Świętym Krzyżu w polskiej kulturze narodowej, red. D. Olszewski, R. Gryz, Kielce 2000, s. 85-103.

Brückner A., Kazania i pieśni: szkice literackie i obyczajowe, Warszawa 1902.

Brückner A., Kazania średniowieczne, cz. 1-3, Kraków 1895-1896.

Jelicz A., Życie codzienne w średniowiecznym Krakowie, Warszawa 1966.

Kowalczyk M., Krakowskie mowy uniwersyteckie z pierwszej połowy XV w., Kraków 1970.

Michałowska T., Literatura polskiego średniowiecza. Leksykon, Warszawa 2011.

Michałowska T., Średniowiecze, Warszawa 2000. 
Polska poezja świecka XV wieku, oprac. M. Włodarski, Wrocław 1997.

Skwierczyński K., Mury Sodomy. Piotra Damianiego „Księga Gomory” i walka z sodomia wśród kleru, Kraków 2011.

Skwierczyński K., Vademecum historii średniowiecznej seksualności, „Przegląd Historyczny” 98, 2007, z. 3, s. 437-443.

\section{Ut non diligat vir uxorem sicut adulteram - sexuality in medieval Poland as seen by the preachers}

\section{Summary}

How can the attitudes of medieval people towards any manifestations of sexuality be examined? The objective of the study is to reveal the utility of sermons in research on sexuality in medieval Poland. Knowing that the content of the studied sermons is frequently set in the reality of everyday life, it is not unfounded to expect that any kinds of behaviour and attitudes criticized and condemned by preachers constitute a credible reflection of the customs typical for the inhabitants of medieval Poland. One can therefore discover what kind of sexually motivated behaviour was permitted, what attitudes were expected and what eluded any control, shaping the reality and customs of medieval Poland. 